\title{
Cotton Candy Flavor
}

National Cancer Institute

\section{Source}

National Cancer Institute. Cotton Candy Flavor. NCI Thesaurus. Code C73382.

A characteristic of a medicinal product, specifying that its most predominant agreeable savor detected by the unified sensation of taste and olfactory receptors resembles cotton candy. 